\title{
Neutron Radiation
}

National Cancer Institute

\section{Source}

National Cancer Institute. Neutron Radiation. NCI Thesaurus. Code C18070.

Radiation of neutrons during radioactive decay. 